\title{
THE LANGUAGE OF THE NEW TESTAMENT
}

\section{Lars Rydbeck}

Critical evaluation of the language of the New Testament has been marked in the last two hundred years by conflicting viewpoints, which can still be heard frequently today. In particular, two positions can be identified:

(1) The language of the New Testament is situated within the context of the historical development of written Greek, stretching over the period from Alexander the Great to the first century A.D. Here one might mention contributions by A. Deissmann, ${ }^{1}$ J.H. Moulton, ${ }^{2}$ A. Wifstrand, ${ }^{3}$ as well as my own ${ }^{4}$ and that of G.H.R. Horsley. 5

(2) The language of the New Testament is unique and must be viewed as an independent phenomenon, outside of and concurrent with the normal development of the Greek language. Some advocates of this view speak of semiticising Greek (e.g., J. Wellhausen 6 ), while others speak of a special form of Christian Greek, an ad hoc language inspired by the Holy Spirit (e.g., N. Turner7).

\footnotetext{
${ }^{1}$ A. Deissmann, Licht vom Osten. Das NT und die neuentdeckten Texte der hellenistisch-römischen Welt (4th ed.; Tübingen, 1923); ET Light from the Ancient East: The New Testament Illustrated by Recently Discovered Texts of the Graeco-Roman World (London, 1927).

2J.H. Moulton, Einleitung in die Sprache des NT (Heidelberg, 1911).

${ }^{3} \mathrm{~A}$. Wifstrand, 'Lukas och den grekiska klassicismen', Svensk exegetisk årsbok 5 (1940) 139-51.

${ }^{4}$ L. Rydbeck, Fachprosa, vermeintliche Volkssprache und NT. Zur Beurteilung der sprachlichen Niveauunterschiede im nachklassischen Griechisch (Lund, 1967); idem, 'Det nytestamentliga språkets inplacering i den samtida språkmiljön' in T. Engberg-Pedersen et al. (eds.), Sproget $i$ hellenismen (Aarhus, 1995).

5G.H.R. Horsley, New Documents Illustrating Early Christianity. Vol. 5.; Linguistic Essays (Marrickville, N.S.W., 1989).

6J. Wellhausen, Einleitung in die drei ersten Evangelien (Berlin, 1911).

${ }^{7}$ N. Turner, Syntax (published as Vol. III of J.H. Moulton, A Grammar of New Testament Greek; Edinburgh, 1965).
} 
If even the most cursory comments in the New Testament are to be attributed greatest importance, it is understandable that the classification of a particular author's linguistic style is given great weight. When one then adds the relatively large number of conceptually difficult texts, it becomes quite understandable why certain exegetes want to use philology to specify at least the linguistic meaning of a particular passage ('how it is to be translated'), whilst others attempt to establish the relative merits of differing philologically possible translations by means of exegetical decisions.

The classification of particular styles of New Testament Greek is also clearly dependent on the scholar's own academic background. A training in classical philology is rare today amongst New Testament exegetes. For help with linguistic details, one therefore has mostly to consult the large, mainly German (though also English) commentaries which appeared around the turn of the century. The commentaries of the French scholar Lagrange are also very helpful in respect of language. Unfortunately, Lagrange's linguistic observations have been largely forgotten today.

One cannot discuss the language of the New Testament without first briefly shedding some light on the over 3000-year history of the Greek language.

So-called classical Attic prose (c. 400 B.C.) is a late phenomenon in the history of Greek. However, it is this uniform Attic (with a substantial [though well assimilated] proportion of Ionic) which is taken up by the rising northern power, Macedonia, as the language of diplomacy in their dealings with the Greeks.

This common Attic then spread by means of Alexander the Great's military conquests throughout the Near East, wherever Greeks settled. Thus Attic becomes the common language of the hellenistic world and henceforth receives the

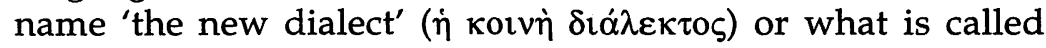
'Koine' ( $\dot{\eta}$ Korvi'; the expression occurs in a text by the Epicurean philosopher Kolotes, who was born around 325 B.C.).

The era of Hellenistic Greek went into decline from 50 B.C. due to the reaction of the pseudo-classical language and stylistics movement, which demanded a return to the writers of 
the classical period and which figures under the name Classicism or Atticism. This classicistic reaction in language meant that most of the literature of the three hundred years before Christ was forgotten and lost. Thanks to Christianity's interest in the Septuagint, however, the largest single text of the Hellenistic period was preserved, and represents, next to the historians Polybius and Diodorus, the most important monument of literary Koine, just as the New Testament is undoubtedly the most important example of a first-century A.D. literary koine still untouched by Classicism. From the second century A.D., however, Atticism then dominated both pagan literary development and the Greek of the first Christian theologians.

Research into Koine has attempted to account not only for the written language (literary Koine) but also for everyday colloquial language, which in the time up to year 0 was naturally developing away from literary Koine with its Attic background. Until the nineteenth century, scholars only referred to manuscript evidence for comparisons with the New Testament. This is especially true of G.B. Winer's influential grammar, which appeared in its first edition as early as 1822.8 In time, inscriptions also began to be adduced as comparative material; by the end of the century, this was true of papyri too. It is the great contribution of Deissmann to have lifted the New Testament out of its linguistic isolation and to have demonstrated by means of the papyri that the phonology, morphology and lexis of the New Testament are germane to the linguistic development of the period. Unfortunately, Deissmann often appears to believe that the papyri reflect the colloquial language of the uneducated populace, and that the similarities between the New Testament and the papyri show the New Testament too to be an exponent of colloquial Hellenistic language. Deissmann worked primarily on lexical issues, occasionally on phonology and morphology, but gave very little attention to syntax, the very area in which questions of word-order were to prove most interesting.

${ }^{8}$ G.B. Winer, Grammatik des neutestamentlichen Sprachidioms (Leipzig, 1822; seventh ed. revised by G. Lünemann, 1867; eighth [incomplete] ed. revised by P.W. Schmiedel, 1894-98). 
Deissmann's preference for viewing the New Testament and the papyri as 'popular language' (especially in Licht vom Osten, the bestseller among academic works of the early twentieth century) is understandable in the light of contemporary views of 'the people'. The New Testament became for him the great book of the people, written by the people, for the people, in the language of the people.

In time, however, it became clear how difficult it was to arrive at the language of the uneducated people. It could only be identified in snippets: here and there, like the untiring dandelion, breaking through the asphalt of written standard Koine. Moreover, it emerged that the papyri had to be interpreted as representatives of standard Koine and not of vulgar Greek, the latter remaining (as it still does today) an unknown quantity.

Thirdly, scholars noticed the high level of uniformity exhibited by Koine as early as 100 B.C. (thus for example the correlation of Polybius with contemporary inscription mater-

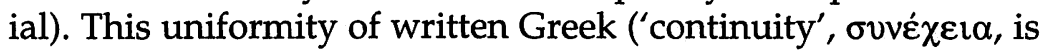
the term preferred by scholarship) may well be the most striking characteristic of the history of Greek up until the $\kappa \alpha \theta \alpha \rho \varepsilon v 0 v \sigma \alpha$ of modern times.

In his captivating lecture 'Geschichte der griechischen Sprache' in 1927, just a few years before his death, U. von Wilamowitz-Moellendorff spoke of the various languages and styles in the development of the Greek language. ${ }^{9}$ He deals not only with the artificial literary language of Homer, the artistic language of Attic tragedy and the idiosyncratic language of Menander's comedy, but also with written Hellenistic in its various styles. The Attic-based Panhellenic written language which developed after Alexander corresponded approximately to the High German of the first half of the twentieth century. Anyone who wanted to share in Greek $\pi \alpha i \delta \varepsilon i \alpha$ learnt literary Koine: the Chaldean Berossus and the Egyptian Manetho, the Carthaginian Hannibal and the Roman Scipio. After Augustus, a classicising variant of literary Koine developed, turning back

${ }^{9} \mathrm{U}$. von Wilamowitz-Moellendorff, Geschichte der griechischen Sprache (Berlin, 1928). 
the linguistic clock by 400 years. In the imperial period, the Christian Church became a guardian of this atticising artistic language, thus holding very different linguistic ambitions from those of the language it found in the New Testament.

In recent decades, scholars have spoken of different variants of written Koine or (following the terminology of Anglo-American linguistics) of 'registers' or a phenomenon of polyglossia,10 synagogal translation Greek, specialist descriptive prose, paraenetic-epistolary Koine etc.

In one of my own works, 11 I suggested a kind of intermediate layer between the Hellenistic literary Koine that we find in Polybius and the true Classicistic prose of the imperial period, referring to correlations between the New Testament and the prose of this intermediate layer, which remained-just as did the New Testament-untouched by Classicism. As has already been hinted, the Greek of the papyri is not that of folk colloquial language, but mostly that of factual prose in the written language. New Testament Greek, therefore, can basically be classified together with factual prose, even if there is some spoken Greek that occasionally appears in Mark.

One might further recall in this context the rule for distinguishing between styles in contemporary literature discovered by Erich Auerbach. ${ }^{12}$ According to this rule, ancient writers always represented so-called low events in a satirical or joking spirit, and it would never have occurred to them to portray so provincial an event as, for example, Peter's denial with such great seriousness. Pagan literature, where everything was so rhetoricised, simply had no eye for the huge swing of the pendulum within just one person.

Neither Hellenistic literary Koine, nor the Atticistic artistic language of the imperial period are monolithic entities. Both contain several levels of literary Koine or Atticistic high prose, as well as, in many cases, personal variants of individual authors.

${ }^{10} \mathrm{~J}$. Blomqvist, 'Diglossifenomen i den hellenistiska grekiskan', in T. Engberg-Pedersen et al. (eds.), Sproget $i$ hellenismen (Aarhus, 1995).

11 Rydbeck, Fachprosa.

12E. Auerbach, Mimesis. Dargestellte Wirklichkeit in der abendländischen Literatur (Bern, 1959), ch. 2. 
The New Testament came into being before the Atticising reaction in language had asserted itself along a wide front. Atticism must be understood as a reactionary linguistic and cultural movement, in contrast to which Hellenistic Koine originated from a conservative linguistic and cultural climate which, though building on attic prose, had permitted itself a relatively high degree of flexibility. Thus the various examples of literary Koine which find expression in the formation of New Testament Greek can be explained: the various translational layers of Septuagint Greek and the representatives of what we call intertestamental literature, especially Wisdom of Solomon, Enoch and the Testament of the Twelve Patriarchs, which influenced the Greek of the Epistles of James and Peter and the Epistle to the Hebrews.

Many influences meet in the New Testament. Of particular importance for the formation of the language of the Synoptics and Acts (as even Deissmann could not deny, despite his pro-Greek attitude) is the Greek of the Septuagint. The Septuagint is for these writers the classic devotional text, to be quoted and freely integrated into literary composition. It is here that we find the root of Lukan classicism, not in imperial-age pagan Classicism (as Wifstrand has shown ${ }^{13}$ in clear polemic against Norden's views ${ }^{14}$ ).

Luke's stylistic borrowing from the phraseology of the Septuagint often disappears from view in modern 'normalising' translations. Taking Luke 9:51-53 as an example, we can compare: (1) the original, (2) the New International Version, and (3) the King James Version. I have italicised in the KJV text literal renditions of some phrases characteristic of the Septuagint.

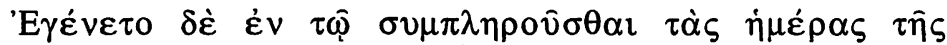

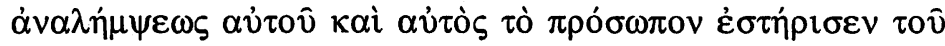

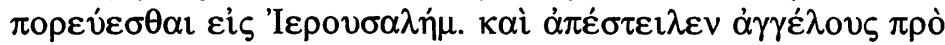

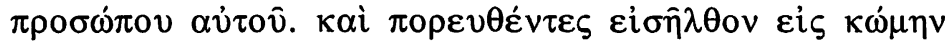

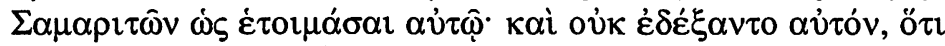

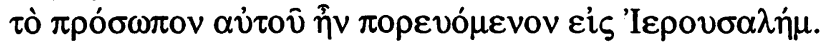

13Wifstrand, 'Lukas och den grekiska klassicismen'.

${ }^{14} \mathrm{E}$. Norden, Die antike Kunstprosa (Bd. 1-2; Leipzig \& Berlin, 1915-18). 
As the time approached for him to be taken up to heaven, Jesus resolutely set out for Jerusalem. And he sent messengers on ahead, who went into a Samaritan village to get things ready for him; but the people there did not welcome him, because he was heading for Jerusalem. (NIV)

And it came to pass, when the time was come that he should be received up, he steadfastly set his face to go to Jerusalem, And sent messengers before his face: and they went, and entered into a village of the Samaritans, to make ready for him. And they did not receive him, because his face was as though he would go to Jerusalem. (KJV)

At least five linguistic styles can be distinguished in the New Testament. These all rest on one common basis with respect to phonology, morphology, syntax (except imitations of Septuagintal translation syntax), word formation and word meanings: the usual written Hoine with forbears in the Hellenistic period. The first category: Paul. The second category: John (and the letters of John); Paul and John are two unique individuals in terms of linguistic style. The third category: the Synoptic Gospels and Acts; this group is characterised by the atmosphere of the Septuagint and common Semitic influences on phraseology and word order. The fourth category: Revelation, the author of which is an idiosyncratic stylist; deviances from normative Greek grammar are intentional. The fifth category: the catholic letters, Hebrews and the Pastorals. This last category is doubly distinct from the other groups. ${ }^{15}$ Firstly, these authors lie closer to the usual Greek style of descriptive, analytic and paraenetic prose than the words of Jesus in the Gospels or the appeals and arguments in Paul; the latter are very coloured by Paul's own personal style with its condensed thought. Secondly, the style of the catholic letters is strikingly similar to that of later Christian literature. The apostolic and later fathers of the church write in a style reminiscent of the letters of James and Peter.

The roots of this linguistic style can be found in the devotional language of the Hellenised Diaspora synagogue.

${ }^{15} \mathrm{Cf}$. A. Wifstrand, 'Stylistic Problems in the Epistles of James and Peter', Studia Theologica I (1947/48) 170-82. 
One could therefore describe Synagogal Greek as biblical or Jewish Greek. One must keep in mind, however, that the Biblical/ Jewish element is restricted to phraseology and sentence structure, whilst phonology, morphology, normative syntax, word formation and most word meanings are completely in line with standard Koine. During the imperial period, the semitic influence gradually disappeared, remaining only in the language of Christian theologians, and the influence of the Septuagint became restricted to allusions and direct quotations, though the linguistic tonal root of the early Church never went completely silent. ${ }^{16}$

${ }^{16}$ This article, translated by Dr Andrew Warren from the German original, is also to appear sub voce 'Bibel' in the new fourth edition of Religion in Geschichte und Gegenwart. 